\title{
GENDER ASYMMETRY IN A MODERN POLITICAL DISCOURSE
}

Bakytgul Khamenoval

Caspian Modern College, Atyrau, Kazakhstan

\section{ABSTRACT}

In this work (article), the author investigates gender asymmetry in modern Kazakhstan society which has social and psychological, is watered - economic scientific measurement. The scientific data base used in this research is wide and authentic enough and can be divided in three groups: first, the social stereotypes and gender aspects, second, the gender and sex theories, imageology, psychology, international politics, third, the scientific sources, devoted to the gender aspects of global and political processes.

\section{JEL CLASSIFICATION \& KEYWORDS}

J48 GENDER DISCRIMINATION INEQUALITY HUMAN RIGHT

\section{INTRODUCTION}

The Relevance of image making of the woman-politician in modern Kazakhstan society has a socio-psychological and politico-economical economic scientific determination.

Certainly, the academic importance is connected with the need of gender inequality research one of which is gender stereotypes. Another actual problem of science is the analysis of the nature of power, its resources and ways of its legitimation and delegitimation. Nevertheless, the following questions were not completely studied: the nature and functions of gender tools; the role of an economic, political, socio-cultural discourse in maintenance and correction of gender instruments; the influence of these discourses on a gender order of modern Kazakhstan society.

\section{The concept of gender: problem statement}

In the socio-psychological terms, the relevance of the problem is connected with the necessity to study the resources of power, which don't involve open violence. Nevertheless, they act as the effective control and the instrument which is actively used in political struggle. Moreover, socio-psychological instruments are the element of power.

The concept of gender as a problem requiring a specific approach emerges in the twentieth century. There are many attempts to justify the importance of this concept, which point to the different moments of occurrence of "gender", that determines social relations, is included as an integral component; this is something recognized in the primary contexts of the word "sex", however, it is not equal to "sex". Thus, the gender is often defined as "a social sex". It is possible to assume that this concept is used originally not as a specification or aspect of the concept "gender" and not as a way of consideration of sex in other "nonbiological" and "non-physiological" optics. At first thought, this word not bearing something new, serves for accurate marking of new, revolutionary, alternative representations in relation to the traditionally used representations. The English word "gender" derives from Latin "genus". Such

I hamenova@bk.ru

www.journals.cz notion of gender, as something similar to the "sex" and only "intersects" with it in physiology, social relationships, behavior, etc., is usually associated with the theoretical innovation of the American psychologist and sexologist John Money. In the article of 1955, he declared a need to study certain sexual deviations in the light of new "gender" understanding of sexuality. The new view makes it possible to point to the biological definiteness of psychological understanding of the word "gender", and unambiguously separate it from physiological understanding (Adorno, 1999, Berger, 1995). It historically developed that women remain in the shadow, so far as concerns human rights. For the majority of groups of fighters for human rights the victim's model usually is the man. During consideration of violations of the rights of the civil and political nature influence of these violations on men is usually considered. What impact it has on the woman is a question are inclined or to ignore at all, or to consider as something "additional" and "specific". Women attract the sympathy of society only if they suffer from tortures and prosecutions of the same sort, as the man. The understanding of need of gender equality (social equality of men and women) at the new qualitative level came to the international community in the second part of the XX century. It is directly connected with judgment in general of human rights. The modern period of their development began after World War II when the United Nations Organization accepted a number of documents on human rights in which the corresponding international standards were registered. Today it seems absolutely natural that all human rights extend to women. But at that time because of various factors of the right of women were pushed aside and restrained. Traditions, prejudices, stereotypes, certain social, economic and political interests - all this disturbed (and still continues to disturb) to establishment of gender equality.

The United Nations-sponsored women's conferences, which took place in Mexico City in 1975, Copenhagen in 1980 , and Nairobi in 1985, were convened to evaluate the status of women and to formulate strategies for women's advancement. These conferences were critical venues at which women came together, debated their differences and discovered their commonalties, and gradually began learning to bridge differences to create a global movement. In the late eighties and early nineties, women in diverse countries took up the human rights framework and began developing the analytic and political tools that together constitute the ideas and practices of women's human rights (Kimmel, 1996).

Taking up the human rights framework has involved a double shift in thinking about human rights and talking about women's lives. Put quite simply, it has entailed examining the human rights framework through a gender lens, and describing women's lives through a human rights framework. In looking at the human rights framework from women's perspectives, women have shown how current human rights definitions and practices fail to account for the ways in which already recognized human rights abuses 
often affect women differently because of their gender. This approach acknowledges the importance of the existing concepts and activities, but also points out that there are dimensions within these received definitions that are gender-specific and that need to be addressed if the mechanisms, programs, and the human rights framework itself are to include and reflect the experiences of the female half of the world's population (Irkhin, 2006).

\section{The question of gender heterogeneity}

The modern world noticeably multiplies quantity of imperatives of social life:power, ecological, medical, humanitarian - that imposes strict requirements to the policy capable to ensure a survival, safety and prosperity of the country. And subjects of political process are indissolubly interconnected. In the increasing rigidity of conditions of a survival the role of women as the stabilizing factor amplifies. But the same severe conditions demand considerable updating of skills, means and methods of participation of women in political process. Therefore, only new era of the international cooperation between the governments and the people in the spirit of partnership, equal international social economic conditions and radical transformations of the relations between women and men concerning comprehensive and equal partnership allows the world to solve XXI century problems. Why gender equality in the political sphere didn't become a reality? We will call the main reasons explaining the lack of progress in understanding of gender equality.

1. It is staked on gender equality de jure that not always effectively protects against different types of discrimination. Women worked much over the legislation, disregarding an overall picture of functioning of society.

2. Specialized institutes concerning the equality work within the structures not always providing enough means for their realization.

These institutes have a limited field of activity and limited power even if they refer to this or that important ministry. Their impact on spheres,in which decisions on life of citizens are made, remains limited, and the undertaken measures within fight for equal opportunities hardly correct the balance violations allowed in various sectors (Ryabov, 1999).

Heterogeneity of a floor assumes that the masculinity and a feminity are non-uniform in itself: there are various types and masculinity, and feminity; the content of these concepts depends on status characteristics of the individual or group (for example, a class, race, ethnicity, sexual orientation).

For the first time, the idea was formulated by the Australian sociologist R. Cornell in the form of the thesis about a multiple masculinity (multiplemasculinities). The masculinity isn't something homogeneous and united; on the contrary, it is necessary to recognize simultaneous (Cornell, 2002) (Scott, 2001)

The existence of various types of a masculinity determined by various social identifiers. Among the factors causing plurality of a masculinity and feminity M. Kimmel, in many respects based on R. Cornell's ideas, allocates the following.

First, the maintenance of a maskulinnost and feminity is unequal in different cultures. Secondly, it differs during the different periods of history.
Thirdly, variability of ideas of men and women is defined by influence of a class, race, ethnicity, the professional status, sexual orientation and other differentiating signs.

Fourthly, it is possible to speak about individual distinctions of a masculinity as the person during the separate periods of the life or in separate situations chooses a line of conduct which significantly deviates from the "standard".

The gender inequality is also a fundamental component of the Millennium Declaration accepted by countries of the UN in 2000. The purposes of development of the Millennium (PDM) create the structure of the measurement of the process of implementation of obligations of the Millennium Declaration. The third purpose unambiguously provides establishment of gender equality and expansion of the rights and opportunities of women that is reflected in the concrete indicators connected with education, employment and decision-making. However, ensuring gender equality is important for performance of all other tasks. Data in breakdown on a gender have to be presented in country reports on results of performance of PDM in appropriate cases.

\section{CONCLUSION}

Important feature of a discourse is that new values are created in the course of reasoning. M. Fouco, characterizing process of establishment of meanings, enters the concept of the mode of power / truth assuming that the truth and the power are inseparably linked.On the one hand, the power itself makes the truth, establishing values: those who is in power, have more chances to be heard, and their truth can be accepted.Political parties, competing for the voter, combat for production of values the victory in this fight means real possibility of implementation of power 5 .

\section{REFERENCES}

Adorno, T. (1999). Authoritarian Personality / Adorno // Psychology and Psychoanalysis power / Ed. DY Raigorodskii. - Samara. T. 2. S. 239245. - ISBN 5-89570-010-1.

Berger, P., Lukman T. (1995). The Social Construction of Reality / P. Berger and T. Lukman. - M .: Mosk. Philosophy. Foundation. - 322 p. - ISBN 5-85691-0362.

Cornell, R. W. (2002). Gender / R.W.Connell. - Cambridge, UK: Polity; Maiden, MA: Blackwell Publishers, - 173 p. ISBN 0745627153.

Irkhin, V. (2006). Sociology of culture: Textbook. Manual/ V. Irkhin - M .: "Exam". - 525 p. - ISBN 5-472-01217-1.

Kimmel, M. (1996). Manhood in America: A Cultural History / M. Kimmel. - New York: Free Press. - 544 p. - ISBN 002874067X.

Ryabov, O.V. (1999). Russian philosophy of femininity (XI-XX centuries)/ OV Ryabov. - Ivanovo Ivan. State University Press. 360 p. - ISBN 5-89729-012-1.

Scott, John (2001). Gender: Useful category of historical analysis / J. Scott // Introduction to Gender Studies. Part 2 - S. 405-437. 